\title{
Potential economic impacts of achieving good environmental status in Black Sea fisheries
}

\author{
$\underline{\text { Ian C. Goulding }}^{1}, \underline{\text { Kim A. Stobberup }}^{1}$ and Tim O'Higgins $^{2}$
}

\begin{abstract}
The Marine Strategy Framework Directive (MSFD) mandates that European Union (EU) member states achieve Good Environmental Status (GEnS) based on an ecosystem-based approach to management. For commercial fisheries, the primary target under the MSFD is one of maximum sustainable yield. Of Black Sea riparian nations, only Romania and Bulgaria are EU member states. Focusing at the supranational level, we review institutions and instruments relevant to management of the Black Sea. The economic values of current fish catches are assessed, and the results of a recent analytical assessment of fish stocks are used to estimate potential future values based on maximum sustainable yields. In the Black Sea region, despite long-standing attempts to improve fisheries management, there remains a lack of effective regional cooperation. Evidence from the scenario analysis suggests that achieving GEnS would not have an undue negative impact on overall fishery sector incomes, and could, with appropriate investments in processing and marketing, deliver increased economic benefits for Black Sea countries. The ongoing policy debate between and within Black Sea coastal states needs to be extended to include recognition of the potential economic and social benefits of effective fisheries management. More work is required to assess returns on investment in interim management measures to deliver GEnS.
\end{abstract}

Key Words: Black Sea; economic impacts; Good Environmental Status; Marine Strategy Framework Directive; maximum sustainable yield; small pelagic fish

\section{INTRODUCTION}

The Black Sea is a "unicum hydrobiologicum" (Knipovich 1932). It is geologically young and is an almost fully enclosed brackish sea with unique biological characteristics (Black Sea Commission 2008). This biological system is part of a larger social-ecological system of interacting environmental and human processes. Traditionally, the Black Sea forms the boundary between Europe and Asia. It is bordered by six nations which have very different social and economic characteristics (see O’Higgins et al., 2014). Each has its exclusive economic zones and related arrangements for fisheries management (Duzgunes and Erdogan 2008). Fig. 1 shows the Black Sea coastal nations and their maritime jurisdictions. Romania and Bulgaria acceded to the European Union (EU) in 2007. This accession carries with it opportunities for sustainable development of the fisheries, as well as obligations for environmental protection, both within the scope of the EU's Common Fisheries Policy and under the Marine Strategy Framework Directive (MSFD) (European Commission 2008). This requires EU member states to take steps to achieve Good Environmental Status (GEnS) of their marine waters through an ecosystem-based approach, based on 11 descriptors. Turkey is also a candidate for accession to the EU, and has taken initial steps to harmonize its fisheries management practices with those of the EU. Despite these positive steps, the Black Sea coastal states have so far not been able to establish an effective collaborative mechanism for the governance of shared and straddling fish stocks, with the result that exploitation levels of most stocks exceed sustainable levels.

The MSFD Descriptor 3 (D3) defines GEnS for commercial fisheries as follows: "Populations of all commercially exploited fish and shellfish are within safe biological limits, exhibiting a population, age, and size distribution that is indicative of a healthy stock" (European Commission 2008). The subsequent Commission Decision specified in more detail the criteria and methodological standards for this descriptor (European Commission 2010). The three criteria and associated indicators are: 3.1 Level of pressure of the fishing activity; 3.2 Reproductive capacity of the stock; and 3.3 Population age and size distribution. The International Council for the Exploration of the Sea (ICES) has proposed a methodology for defining indicators for D3 where there are analytical stock assessments in place, with the primary management target of establishing catch limits at a level that will deliver maximum sustainable yield (MSY) over the long term (ICES 2012). This is also consistent with the EU's reformed Common Fisheries Policy, launched on 1 January 2014.

Fig. 1. Map of the Black Sea region showing the riparian states and exclusive economic zones. Waters under the jurisdiction of the European Union (EU) are shown in blue. The exclusive economic zone for Turkey, a candidate for accession to the EU, is shown in pale blue.

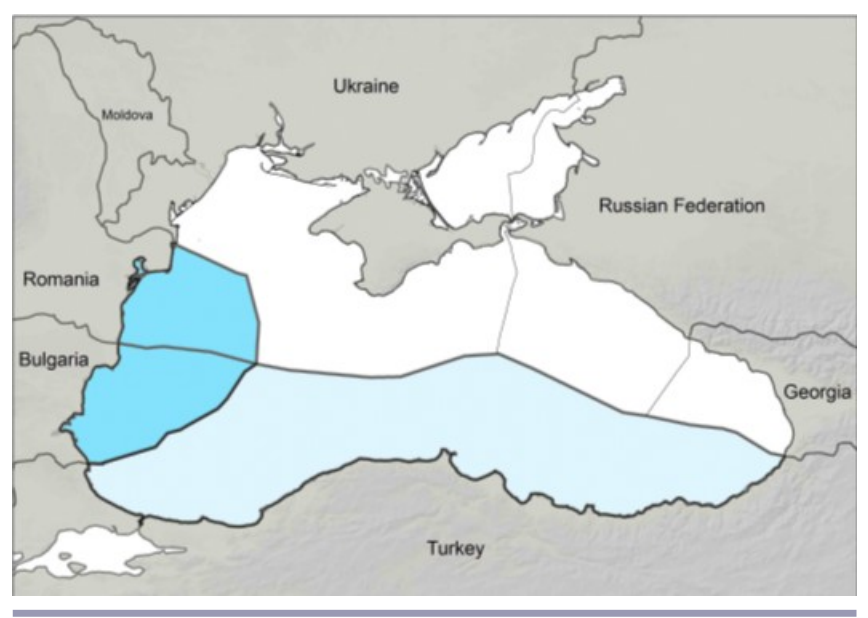

Until now there has been no detailed quantitative assessment of the economic implications of establishing sustainable commercial fisheries in the Black Sea. Recently published data from analytical 
assessments of fish stocks provide an opportunity to estimate the potential MSY for some Black Sea stocks. The aim of this study is therefore to assess potential future economic benefits to Black Sea countries under a scenario of GEnS, and to consider the potential for new economic analyses to play a role in the policy debate regarding the establishment of governance arrangements.

\section{GOVERNANCE ARRANGEMENTS FOR BLACK SEA FISHERIES}

There are a number of legislative and institutional approaches for managing the marine environment of the Black Sea. They operate at different scales, including national, subregional, and global. However, there is no regional fisheries management organization (RFMO) that could provide a basis for a fisheries management framework that is enforceable in international law.

The environmental strategy for the Black Sea is established under the Bucharest Convention on the Protection of the Black Sea Against Pollution. The Convention is signed by all of the Black Sea nations and is implemented by the Black Sea Commission, with the EU and other organizations participating as observers. The Convention contains a commitment toward integrated management. The "sustainable use of commercial fish stocks and other marine living resources" is a stated priority, to be achieved through a signed and enforced regional fisheries agreement (Black Sea Commission 2009). Recent efforts, which have focused on establishing a Legally Binding Document on Fisheries and the Conservation of Living Marine Resources within the framework of the Black Sea Commission, have not been successful.

The General Fisheries Council for the Mediterranean (GFCM) was established to promote development, conservation, rational management, and best utilization of living marine resources. It provides a forum for collaboration on fisheries research and management (Rätz 2010) but cannot produce binding resolutions. Only Turkey, Romania, and Bulgaria are members. The Agreement on the Conservation of Cetaceans of the Black Sea, Mediterranean Sea and Contiguous Atlantic Area was designed to conserve populations of endangered cetaceans. It allows for measures to prohibit the taking of cetaceans and control of exotic species, but neither Turkey nor the Russian Federation are involved. Turkey is not a signatory of the UN Convention on the Law of the Sea (UNCLOS), which binds parties to sustainable management of their fishery resources. The Convention also requires recognition of 200-mile exclusive economic zones, which would impinge on Turkey's territorial claims in the Mediterranean.

Currently, the requirement under the MSFD to establish catch limits within the Black Sea in line with MSY applies only to Romania and Bulgaria. According to Article 3(1) of the Directive, it covers the Romanian and Bulgarian exclusive economic zones to a boundary of up to 200 nautical miles from the coast, which accounts for approximately $14 \%$ of the total area of the Black Sea (Suárez De Vivero 2012). Any future accession of Turkey to the EU would see the EU's jurisdiction expand to just over $50 \%$ of the Black Sea. At the national level, each country has its own specific management structures, rules, and regulations regarding fisheries management, some of which include bilateral fishing agreements between nations (see Duzgunes and Erdogan [2008] for detailed accounts). These rules are not consistently enforced.

\section{Environmental condition of the Black Sea}

Human activities within the Black Sea and its catchment area have resulted in a series of environmental crises, from fisheries collapses (Daskalov et al. 2007, Black Sea Commission 2008) to severe eutrophication (Cociasu et al. 1996, Bodeanu 2002, Mee et al. 2005) and catastrophic invasions of nonindigenous species (Oguz et al. 2008). Declines in catches and stocks of high value commercial fish species, particularly of predators, were evident by the early 1970s (Prodanov et al. 1997). They were followed by collapses in the anchovy and sprat stocks in the late 1980s and early 1990s, respectively (Black Sea Commission 2008).

The ecological regimes in the Black Sea are well documented (GFCM Secretariat 2011). Essentially, they fall within four phases, as follows:

- 1960s: pristine ecosystem involving relatively low phytoplankton levels, relatively high zooplankton standing stocks, low stock levels of small pelagic fish, and relatively high stocks of large pelagic and predator fish species;

- early 1970s: eutrophication phase, combined with overfishing of top predators, leading to a regime shift to domination of small planktivorous fish species, with significant increases in catches;

- late 1980s: population explosion of an introduced ctenophore, combined with extreme climatic conditions, excessive fishing pressure (and possible predation on fish eggs and larvae), leading to catastrophic collapse of small pelagic fish stocks;

- 1990s and 2000s: gradual but cyclical recovery of small pelagic fish stocks and catches, with an increase in zooplankton biomass and a decrease in phytoplankton and ctenophores. There has been no recovery of top predator stocks due to continued excessive fishing pressure.

The direct causes of the fisheries collapses in the Black Sea were two-fold: overfishing (Black Sea Commission 2008) and the arrival of the nonindigenous comb jelly Mnemiopsis leidyi, a predator and competitor of the major small pelagic fisheries species (Oguz et al. 2008). Following collapses in the late 1980s and early 1990s, both anchovy and sprat stocks had recovered by 2005 (Daskalov et al. 2010).

The current status of commercial fisheries is that stocks of important demersal species such as turbot, red mullet, and bluefish are overexploited. At least two species of sturgeon are considered to be critically endangered (IUCN 2012). Some stocks of small pelagic species (and occasionally bonito) are reasonably healthy, while stocks of most other commercial species are low and decreasing. The stocks of the commercially important invasive gastropod, the Rapana whelk, appear to be increasing. Daskalov et al. (2007) and others have argued that the current environment status of the Black Sea may be largely due to a trophic cascade driven by the decline in top predators, leading to uncontrolled phytoplankton blooms. 
Table 1. Average catches by species and values of fish in the Black Sea, 2006-2010 (value in 2011 prices).

\begin{tabular}{|c|c|c|c|c|c|c|c|c|c|c|c|c|c|c|c|}
\hline \multirow[b]{2}{*}{ Species } & \multirow[b]{2}{*}{$\begin{array}{l}2011 \text { Price } \\
(\text { EUR/kg) } \dagger\end{array}$} & \multicolumn{2}{|c|}{ Bulgaria } & \multicolumn{2}{|c|}{ Georgia } & \multicolumn{2}{|c|}{ Romania } & \multicolumn{2}{|c|}{$\begin{array}{c}\text { Russian } \\
\text { Federation }\end{array}$} & \multicolumn{2}{|c|}{ Turkey } & \multicolumn{2}{|c|}{ Ukraine } & \multicolumn{2}{|c|}{ TOTAL } \\
\hline & & $\begin{array}{l}\text { Catch } \\
(\mathrm{t})\end{array}$ & $\begin{array}{c}\text { Value } \\
(€)\end{array}$ & $\begin{array}{c}\text { Catch } \\
\text { (t) }\end{array}$ & $\begin{array}{c}\text { Value } \\
(€)\end{array}$ & $\begin{array}{l}\text { Catch } \\
(\mathrm{t})\end{array}$ & $\begin{array}{c}\text { Value } \\
(€)\end{array}$ & $\begin{array}{l}\text { Catch } \\
\text { (t) }\end{array}$ & $\begin{array}{c}\text { Value } \\
(€)\end{array}$ & $\begin{array}{l}\text { Catch } \\
\text { (t) }\end{array}$ & $\begin{array}{c}\text { Value } \\
(€)\end{array}$ & $\begin{array}{l}\text { Catch } \\
\text { (t) }\end{array}$ & $\begin{array}{c}\text { Value } \\
(€)\end{array}$ & $\begin{array}{l}\text { Catch } \\
(\mathrm{t})\end{array}$ & $\begin{array}{c}\text { Value } \\
(€)\end{array}$ \\
\hline Whiting & 2.35 & 7 & 15,494 & 25 & 57,752 & 44 & 102,357 & 67 & 156,822 & 11,234 & $26,374,321$ & 24 & 57,282 & 11,400 & $26,764,029$ \\
\hline Turbot & 15.12 & 47 & 710,648 & - & - & 47 & 704,600 & - & - & 550 & $8,313,070$ & 254 & $3,847,479$ & 898 & $13,575,797$ \\
\hline $\begin{array}{l}\text { European } \\
\text { anchovyt }\end{array}$ & 0.79 & 40 & 31,746 & 20,321 & $16,047,801$ & 27 & 21,006 & 9,654 & $7,624,076$ & 259,113 & $120,155,992$ & 12,919 & $10,202,145$ & 302,075 & $154,082,765$ \\
\hline Sardine & 0.86 & 2 & 2,060 & - & - & - & - & - & - & 7,068 & $6,066,609$ & - & - & 7,070 & $6,068,670$ \\
\hline $\begin{array}{l}\text { European } \\
\text { sprat }\end{array}$ & 0.31 & 3,708 & $1,161,859$ & - & - & 215 & 67,298 & 7,978 & $2,499,482$ & 33,702 & $10,559,058$ & 21,938 & $6,873,223$ & 67,541 & $21,160,920$ \\
\hline Grey mullet & 2.09 & 13 & 28,008 & 5 & 9,615 & 10 & 21,319 & 2,274 & $4,752,535$ & 3,041 & $6,355,664$ & 6,022 & $12,587,257$ & 11,365 & $23,754,397$ \\
\hline Breams & 8.94 & - & - & - & - & - & - & - & - & 142 & $1,267,680$ & - & - & 142 & $1,267,680$ \\
\hline Seabasses & 8.97 & - & - & - & - & - & - & - & - & 134 & $1,206,139$ & - & - & 134 & $1,206,139$ \\
\hline Bluefish & 5.18 & 31 & 162,660 & - & - & - & - & - & - & 5,149 & $26,675,218$ & - & - & 5,181 & $26,837,878$ \\
\hline Mussels & 0.47 & 35 & 16,186 & - & - & 3 & 1,497 & - & - & 1,316 & 615,733 & 379 & 177,113 & 1,733 & 810,530 \\
\hline Red mullet & 7.41 & 44 & 328,808 & 1 & 10,368 & 1 & 4,443 & - & - & 2,751 & $20,371,268$ & 77 & 571,859 & 2,874 & $21,286,746$ \\
\hline $\begin{array}{l}\text { Mediterranean } \\
\text { horse } \\
\text { mackerel }\end{array}$ & 1.80 & 140 & 252,721 & 26 & 47,588 & 10 & 18,026 & 156 & 281,562 & 16,803 & $30,288,670$ & 307 & 554,148 & 17,443 & $31,442,714$ \\
\hline $\begin{array}{l}\text { Atlantic } \\
\text { horse } \\
\text { mackerel }\end{array}$ & 1.80 & - & - & - & - & - & - & - & - & 6,304 & $11,362,712$ & - & - & 6,304 & $11,362,712$ \\
\hline Mackerels & 3.77 & 0 & 754 & - & - & - & - & - & - & 527 & $1,986,239$ & - & - & 527 & $1,986,994$ \\
\hline Rapana & 0.45 & 3,400 & $1,546,781$ & 470 & 214,002 & 0 & 182 & 6 & 2,730 & 9,718 & $4,421,064$ & 202 & 91,988 & 13,797 & $6,276,747$ \\
\hline Venus clams & 0.30 & - & - & - & - & - & - & - & - & 36,691 & $11,180,397$ & - & - & 36,691 & $11,180,397$ \\
\hline Others & 3.04 & 66 & 201,765 & 4 & 13,370 & 19 & 57,734 & 125 & 378,613 & 1,252 & $3,803,814$ & 163 & 495,296 & 1,629 & $4,950,591$ \\
\hline Total & & 7,535 & $4,459,491$ & 20,853 & $16,400,495$ & 375 & 998,462 & 20,260 & $15,695,820$ & 395,494 & $291,003,649$ & 42,286 & $35,457,789$ & 486,804 & $364,015,706$ \\
\hline
\end{tabular}

Fish catches and landings

The total fish landings for each Black Sea nation (2006-2010) are shown in Table 1. Landings of small pelagic species (anchovy, sprat, two species of horse mackerel, and sardine) make up more than $82 \%$ of the annual Black Sea fish catch by weight. Anchovy is the principal catch, making up five times the catch of sprat (the second largest) by weight in the last decade (Daskalov et al. 2010). The lawful fishing activities of each nation are largely restricted to their respective zones, though $10-50 \%$ of the anchovy landed in Turkish ports is caught in Georgian waters (Öztürk et al. 2011; Knudsen, personal communication). Thus, the spatial extent of fishing pressure is reasonably well constrained in the southern part of the Black Sea. However, the spatial scale of the stocks is regional, with most species represented by a single stock that (especially in the case of pelagic fish) straddles or migrates between maritime jurisdictions.

\section{Demand for and utilization of fish}

We estimate that the average annual fish catches in the Black Sea from 2006 to 2010 were valued at about $€ 364$ million. The catch is either consumed directly within the Black Sea nations (FAO 2008) or is processed as fishmeal for internal consumption and for export (Yildirim 2006). Turkish fisheries account for $81 \%$ by weight of total Black Sea fish catches (STECF 2011). The Turkish population is growing at a rate of about $1.2 \%$ per annum and has a life expectancy of approximately 72 years (World Bank 2011). Demand for fish, for direct consumption and for the secondary product of fishmeal (e.g., poultry and farmed fish), are increasing in line with domestic economic growth (Temmuz 2010). Therefore, internal demand for fish in Turkey and the economic pressure on fishers to meet this demand are most likely to continue increasing for several decades.

In 2011, 56\% of Turkey's anchovy catch was used for fishmeal (Turkish Statistical Institute 2012). National and export market demand for fishmeal from sprat and anchovy is a driver of Black Sea small pelagic fisheries (Taçon and Metian 2009, Knudsen et al. 2010). A study by a World Bank Project, "Fish Marketing in Turkey" (MacAlister Elliott and Partners 1995), indicated that fishmeal factories receive anchovy of sizes and quality grades suitable for human consumption ( $>9 \mathrm{~cm}$ minimum market size), as well as anchovy mixed with sprat, and undersized and spoilt fish. Fishers make marketing decisions based on spot prices determined by catch composition and volume of supply on the day. On average, $25 \%$ by weight of 22 samples of fish that entered five fishmeal plants was anchovy of good quality and marketable size. The proportion of fish meeting these criteria varied between batches from $2 \%$ to $72 \%$. Overall, $16 \%$ of anchovy that entered fishmeal plants during the 1994/95 season was potentially reclaimable for human consumption, which suggests a significant underutilization of this catch and the potential for delivering greater economic benefits. However, the continued use of traditional vessel design (bulk handling, lack of refrigeration), lack of shore-based infrastructure (specialized handling, grading, and freezing capacity), and joint ownership of fishmeal production and fleets prevent fishers from gaining these benefits.

\section{Prospects for achieving Good Environmental Status}

While the introduction of invasive species may represent an irreversible regime shift in the marine environment, there remains the potential for optimizing fisheries management to safeguard 
the delivery of sustainable ecosystem benefits in the future. This would arguably represent the best-case scenario, and therefore the achievement of GEnS. However, improving the environmental management of the Black Sea presents significant social, economic, political, and ecological challenges.

In 2011, the European Parliament passed a resolution on the current and future management of Black Sea fisheries which called on the Commission to use all diplomatic and financial means available to it to help achieve concrete results regarding sustainable fisheries (European Union 2011). The resolution also underlined the need to "examine in the long term the creation of a Regional Fisheries Management Organization, which would coordinate scientific research, analyze the situation of fish stocks and carry out special policies regarding observation of endangered species" and noted that "this Organization could also make suggestions regarding the level of the fisheries multiannual management plans and distribute the quotas for the countries bordering the Black Sea."

However, there has been insufficient commonly held political will for creating an RFMO for the Black Sea. This can be attributed to the inherent geopolitical instability within the region (with two Black Sea coastal regions, Abkhazia and more recently Crimea, likely to remain under disputed jurisdiction for some time), as well as deeper linguistic and cultural differences. Furthermore, there are substantial differences in terms of economic reform and the quality of governance among the different countries of the region, allowing geopolitical considerations to become an obstacle to environmental policy development and cooperation (Vassileva 2011). As a result, in Russia, Ukraine, and Georgia, fisheries is subsumed within other nonenvironmental strategic priorities and does not feature highly on the political agenda. Overall, until Turkey, as the largest fishing nation of the six, determines to take action on fisheries management, no progress can be expected.

Until now, arguments in favor of the introduction of fisheries management have been based largely on environmental improvement for its own good, and the economic arguments have not been investigated in any substantive detail. There is a need to apply a structured quantitative approach to assessing the economic impacts of achieving GEnS in commercial fisheries, with a view to widening the political debate on introducing a regional fisheries management regime.

\section{METHODS}

The current scenario for fish production of the Black Sea was derived from catches reported in the FAO Fisheries Global Information System (FIGIS 2013) database. For potential future catches under a scenario of effective fisheries management, the estimated MSY was adopted as the maximum catch that can be generated under GEnS. This is consistent with Descriptor 3 (Commercial Fisheries) of the EU's MSFD, and is the management objective for EU fish stocks under the reformed Common Fisheries Policy. MSY is defined as the largest average catch or yield that can be taken continuously from a stock under existing environmental conditions (FAO 2006). The concept was developed in the 1930s as part of the theory of surplus production models or "Schaefer models" (Sparre and Venema 1998), which are still very much in use (Hilborn and Walters 1992, Quinn and Deriso 1999, Haddon 2001, Cadima 2003, Hoggarth et al. 2006). The theory has since developed to consider nonequilibrium conditions, and these models are now referred to as biomass dynamic models. In these models, the stock is considered to be a bulk of biomass, and the model considers effects of fishing effort and yield on this biomass, thus ignoring the effects of factors such as growth and mortality.

Estimates of MSY can be highly variable since they depend on factors such as growth of fish, stock size, size of the spawning stock biomass, recruitment of young fish, and proportion of the stock harvested by fishing (fishing mortality rate or F). Other important factors such as variation in recruitment, natural mortality, and environmental conditions can affect the "natural" level of biomass of a stock, and for most fisheries, the catch limits required to maintain stocks at MSY are therefore likely to vary from year to year.

Data on the biological status of Black Sea fish stocks were derived from the November 2011 report of the Expert Working Group on Assessment of Black Sea Stocks (EWGBS 2011), published by the Scientific Technical and Economic Committee for Fisheries of the European Commission, which is charged with delivering scientific advice for fisheries management decisions in the EU. This provides the most reliable and up-to-date information on the status of fishery resources in the Black Sea. However, estimates of sustainable catch levels (i.e., conservative estimates of MSY) are specified for only two stocks (sprat and anchovy) due to presumed uncertainty of the assessment results for the other stocks. For these other stocks, for which analytical assessment was not available, an alternative approach to the setting of MSYbased reference values for stocks was required.

We therefore applied Cadima's formula (Cadima 2003) to obtain a first estimate of MSY for a further three stocks (turbot, whiting, and horse mackerel), using catch and biomass estimates provided in the EWGBS (2011) report. The formula is a generalized version of the well-known estimator prepared by Gulland (1971) and further developed by Sparre and Venema (1998). The method is frequently used in fisheries where catch and effort time series data are not yet available but where biomass estimates are occasionally obtained from, for instance, trawl and acoustic surveys. Cadima's formula is expressed as

MSY $=0.5 \times Z \times B$

where $B$ is the average (annual) biomass, and $Z$ is the total mortality rate per year. This can be rewritten as

$\mathrm{MSY}=0.5 \times(Y+M \times \mathrm{B})$

where $Y$ is the total catch in a year, $B$ is the average biomass in the same year, and $M$ is the natural mortality rate per year.

The estimates of natural mortality and biomass were taken from the EWGBS (2011) report in order to obtain consistent estimates. Spawning stock biomass was used instead of mean biomass, thus providing a more conservative estimate of MSY. The data points for estimating MSY were chosen as representing as wide a range of exploitation scenarios as possible during the available time series, although all the available data were used in the case of horse mackerel. As a means of illustrating the shift in trophic levels associated with GEnS of the stocks, the trophic index under each scenario was estimated using the method described by Pauly et al. (1998) and species-specific trophic indicators obtained from Fishbase (Froese and Pauly 2011). 
Table 2. Assessment of Black Sea stocks, including advice given on the exploitation of the stocks and estimates of maximum sustainable yield $(\mathrm{MSY})(\mathrm{F}=$ fishing mortality; $\mathrm{E}=$ exploitation rate; Emsy = exploitation rate at MSY).

\begin{tabular}{|c|c|c|c|c|c|c|}
\hline Species & $\begin{array}{c}\text { Spawning stock } \\
\text { biomass level } \\
\text { (SSB } \\
\end{array}$ & Recruitment & Exploitation level & $\begin{array}{c}\text { Advice based on } \\
\text { proposed Limit } \\
\text { Reference Point (LRP) }\end{array}$ & Comment & $\begin{array}{l}\text { MSY preliminary } \\
\text { estimate }\end{array}$ \\
\hline Sprat & $\begin{array}{l}\text { Medium to } \\
\text { high }\end{array}$ & $\begin{array}{l}\text { Assumed to be } \\
\text { good }\end{array}$ & $\begin{array}{c}\mathrm{E}=0.38, \text { which is below } \\
\text { the proposed LRP of } \\
\text { Emsy } \leq 0.4 \\
\text { (sustainably exploited) }\end{array}$ & $\begin{array}{l}90,000-100,000 \mathrm{t} \\
\text { assuming stable } \\
\text { recruitment and } \\
\text { environmental } \\
\text { conditions }\end{array}$ & $\begin{array}{l}\text { Use advice as a } \\
\text { preliminary proxy } \\
\text { for fishing under } \\
\text { MSY }\end{array}$ & $100,000 \mathrm{t}$ \\
\hline Turbot & Historic low & $\begin{array}{l}\text { Assumed to be } \\
\text { improving }\end{array}$ & $\begin{array}{c}\mathrm{F}=0.6-0.8 \text { is well above } \\
\text { the proposed LRP of } \\
\text { Fmsy } \leq 0.18 \\
\text { (overexploited) }\end{array}$ & $\begin{array}{l}\text { Reduce catches to lowest } \\
\text { possible level } \\
\text { (current catches at } 600 \mathrm{t} \\
\text { and decreasing) }\end{array}$ & $\begin{array}{l}\text { Use Cadima's } \\
\text { empirical equation } \\
\text { for a preliminary } \\
\text { estimate of MSY }\end{array}$ & $\begin{array}{c}1685 \mathrm{t} \\
\text { (range } 660-3300 \mathrm{t}) \\
\text { Applicable when stock } \\
\text { has been rebuilt }\end{array}$ \\
\hline Anchovy & Stable & Variable & $\begin{array}{c}\mathrm{F}=0.62 \text { is well above the } \\
\text { Fmsy }=0.41, \\
\text { corresponding to the } \\
\text { proposed LRP of } \mathrm{E} \leq 0.4 \\
\text { (subject to overfishing) }\end{array}$ & $\begin{array}{c}\text { 200,000 t assuming } \\
\text { stable recruitment and } \\
\text { environmental } \\
\text { conditions }\end{array}$ & $\begin{array}{l}\text { Use advice as a } \\
\text { preliminary proxy } \\
\text { for fishing under } \\
\text { MSY }\end{array}$ & $200,000 \mathrm{t}$ \\
\hline Whiting & Variable & Variable & $\begin{array}{c}\mathrm{F}=0.59 \text { is well above the } \\
\text { proposed Fmsy } \leq 0.4 \\
\text { (subject to overfishing) }\end{array}$ & $\begin{array}{l}8500 \mathrm{t} \text { under current } \\
\text { conditions }\end{array}$ & $\begin{array}{l}\text { Use Cadima's } \\
\text { empirical equation } \\
\text { for a preliminary } \\
\text { estimate of MSY }\end{array}$ & $\begin{array}{c}20,500 \mathrm{t} \\
\text { (range } 14,000- \\
25,650 \mathrm{t} \text { ) } \\
\text { Applicable when stock } \\
\text { has stabilized at high } \\
\text { SSB level }\end{array}$ \\
\hline $\begin{array}{c}\text { Horse } \\
\text { mackerel }\end{array}$ & Low level & Variable & $\begin{array}{l}\text { Not given due to } \\
\text { inconsistencies in the data } \\
\text { (appears to be } \\
\text { overexploited) }\end{array}$ & $\begin{array}{l}\text { Estimated 17,443 t (not } \\
\text { given in EWG-11-16) }\end{array}$ & $\begin{array}{l}\text { Use Cadima's } \\
\text { empirical equation } \\
\text { for a preliminary } \\
\text { estimate of MSY }\end{array}$ & $\begin{array}{l}16,850 \mathrm{t} \text { (range } \\
12,500-21,200 \mathrm{t}) \\
\text { Applicable when stock } \\
\text { has stabilized at higher } \\
\text { SSB level }\end{array}$ \\
\hline
\end{tabular}

Source: EWGBS (2011), STECF (2011)

Economic impacts on coastal states of the Black Sea under current and future management scenarios were estimated based on corresponding catch estimates and unit catch values derived from the most recently available (2011) Turkish fisheries statistics (Turkish Statistical Institute 2012). The economic value added by fishery sector enterprises was estimated using the catch value as a proxy. This approach overestimates value added in fishing activities since it does not account for the cost of inputs. However, this is compensated by a corresponding underestimation of the value added in associated up- and down-stream activities (such as vessel construction and processing, respectively) since this is not accounted for. All values were calculated at 2011 prices. Additional data on utilization of small pelagic fish for fishmeal were derived from Turkish Fishery Statistics (Turkish Statistical Institute 2012) and the Study of Fish Marketing in Turkey (MacAlister Elliott and Partners 1995).

\section{RESULTS}

Potential future fishery yields under Good Environmental Status A synthesis of the results of the assessment for five key stocks drawn from the work of the EWGBS is presented in Table 2. These stocks account for about $83 \%$ of total catches in the Black Sea. Only sprat is considered to be exploited sustainably. In the case of other species (anchovy, horse mackerel, turbot, and whiting), there is a need to rebuild the stock (i.e., to allow spawning stock biomass to increase). Estimates of MSY using either the EWGBS data (for sprat and anchovy) or Cadima's formula (for the remaining species) are shown in the final column of Table 2. The details of the application of Cadima's formula are shown in Table 3.

MSY estimates varied considerably between years, reflecting the variation in reported catches and uncertainties associated with biomass estimates. The data suggest that the main feature of the MSY scenario in the Black Sea would be a substantially lower annual anchovy catch of 200,000 tonnes compared to the recent average levels of 302,074 tonnes. Following recovery to MSY, the stocks of all the other species considered could sustain increased catches compared to recent historical levels. Compared to 2010, catches of turbot, whiting, and horse mackerel would increase by $79 \%, 23 \%$, and $26 \%$, respectively, delivering an estimated additional 8000 tonnes annually.

In the case of whiting, MSY may have been overestimated. The rather high estimate of natural mortality (0.6) assumed by the EWGBS may be part of the reason; a lower range of $0.2-0.4$ is normally assumed for gadoid species (e.g., Pauly 1980, Sinclair 2001, Brodziak et al. 2009). Nonetheless, the value was maintained for the sake of consistency with EWGBS results.

An important aspect in relation to the whiting stock is the strong recruitment in recent years and the building up of the spawning stock. The EWGBS indicates that the stock is subject to overfishing, and currently advises a fishing mortality not higher than 0.4 , which corresponds to a yield of 8500 tonnes under current conditions, which is much lower than the estimated MSY 
(20,500 tonnes). However, one would expect the scientific advice to allow for increases in total allowable catches in the near future, considering the improving state of the stock.

Table 3. Application of Cadima's formula to estimate maximum sustainable yield (MSY) of turbot, whiting, and horse mackerel stocks in the Black Sea.

\begin{tabular}{|c|c|c|c|}
\hline Species/year & Catch & $\begin{array}{l}\text { Biomass } \\
\text { (tonnes) }\end{array}$ & MSY \\
\hline \multicolumn{4}{|c|}{ Turbot $(\mathrm{M}=0.19) \dagger$} \\
\hline 1980 & 2,843 & 20,000 & 3,322 \\
\hline 1990 & 1,393 & 3,000 & 982 \\
\hline 2000 & 2,789 & 4,000 & 1,775 \\
\hline 2010 & 943 & 2,000 & 662 \\
\hline mean & & 7,250 & 1,685 \\
\hline \multicolumn{4}{|c|}{ Whiting $(\mathrm{M}=0.6)$} \\
\hline 1995 & 16,628 & 41,081 & 20,638 \\
\hline 2000 & 14,103 & 49,364 & 21,861 \\
\hline 2005 & 6,511 & 35,858 & 14,013 \\
\hline 2010 & 16,656 & 57,739 & 25,650 \\
\hline mean & & 46,011 & 20,540 \\
\hline \multicolumn{4}{|c|}{ Horse mackerel $(\mathrm{M}=0.4)$} \\
\hline 2005 & 17,602 & 36,378 & 16,077 \\
\hline 2006 & 13,625 & 42,208 & 15,254 \\
\hline 2007 & 17,886 & 55,846 & 20,112 \\
\hline 2008 & 20,843 & 54,006 & 21,223 \\
\hline 2009 & 16,489 & 38,349 & 15,914 \\
\hline 2010 & 13,406 & 29,302 & 12,563 \\
\hline mean & & 42,682 & 16,857 \\
\hline \multicolumn{4}{|c|}{$\begin{array}{l}\dagger \mathrm{M} \text { is the assumed natural mortality used by the Expert Working } \\
\text { Group on Assessment of Black Sea Stocks. } \\
\text { Source: EWGBS (2011), STECF (2011) }\end{array}$} \\
\hline
\end{tabular}

There was a slight shift toward a higher overall trophic index, from 3.14 to 3.18, when fishing at MSY (Table 4). This reflects the higher level of catches of species at higher trophic levels (specifically the predator species of turbot, whiting, and horse mackerel). However, because planktivorous small pelagic species still dominate the catches in terms of volume, the overall change in trophic index is slight since the index presents a weighted average of all species in the fishery.

\section{Potential changes in economic yields under Good Environmental Status}

A comparison of the estimated value added of 2011 catches with catches under the MSY scenario is shown in Table 5. It was assumed that catches of species for which no MSY estimates were available would remain unchanged from the 2006-2010 value. These species account for $15 \%$ of the volume of catches (20062010 ) and $30 \%$ of the value. An additional benefit of improved governance of the fishery sector could be better utilization of the catch. In particular, the practice in Turkey of using more than half of the anchovy catch for reduction to fishmeal suggests that there may be opportunities for recovery of some of this material. Applying the factor of a rate of $16 \%$ of fishmeal inputs recoverable for human consumption (based on the data from the unpublished report by Macalister Elliott and Partners 1995) suggests that an average improvement of economic yields of $11 \%$ could be achieved (Table 6).
Table 4. Trophic index of five Black Sea stocks under current and Good Environmental Status (GEnS) scenarios. $(\mathrm{MSY}=$ maximum sustainable yield)

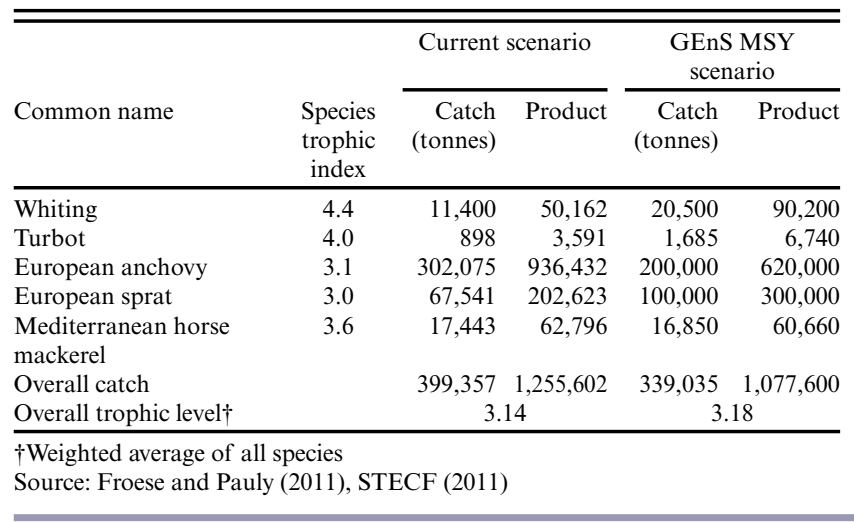

Table 5. Estimated value added of current catches and catches under a maximum sustainable yield (MSY) scenario.

\begin{tabular}{|c|c|c|c|c|}
\hline \multirow[b]{2}{*}{ Common name } & \multicolumn{2}{|c|}{$\begin{array}{r}\text { Current scenario } \\
\text { (ave. 2006-2010) }\end{array}$} & \multicolumn{2}{|c|}{ MSY scenario } \\
\hline & $\begin{array}{r}\text { Catch } \\
(\mathrm{t}) \\
\end{array}$ & $\begin{array}{r}\text { Value } \\
(€) !\end{array}$ & $\begin{array}{r}\text { MSY } \\
(\mathrm{t}) \\
\end{array}$ & $\begin{array}{r}\text { Value } \\
(€)^{2} \\
\end{array}$ \\
\hline Whiting $\dagger$ & 11,400 & $26,764,029$ & 20,500 & $48,126,609$ \\
\hline Turbot $\uparrow$ & 898 & $13,575,797$ & 1,685 & $25,477,489$ \\
\hline European anchovy & 302,075 & $154,082,765$ & 200,000 & $102,016,292$ \\
\hline Sardine $\dagger$ & 7,070 & $6,068,670$ & 7,070 & $6,068,670$ \\
\hline European sprat $\dagger$ & 67,541 & $21,160,920$ & 100,000 & $31,330,472$ \\
\hline Grey mullets & 11,365 & $23,754,397$ & 11,365 & $23,754,397$ \\
\hline Breams & 142 & $1,267,680$ & 142 & $1,267,680$ \\
\hline Seabc & 134 & $1,206,139$ & 134 & $1,206,139$ \\
\hline Bluefish & 5,181 & $26,837,878$ & 5,181 & $26,837,878$ \\
\hline Mussels & 1,733 & 810,530 & 1,733 & 810,530 \\
\hline Red mullet & 2,874 & $21,286,746$ & 2,874 & $21,286,746$ \\
\hline $\begin{array}{l}\text { Mediterranean horse } \\
\text { mackerel } \dagger\end{array}$ & 17,443 & $31,442,714$ & 16,850 & $30,373,391$ \\
\hline Atlantic horse mackerel & 6,304 & $11,362,712$ & 6,304 & $11,362,712$ \\
\hline Mackerels & 527 & $1,986,994$ & 527 & $1,986,994$ \\
\hline Rapana & 13,797 & $6,276,747$ & 13,797 & $6,276,747$ \\
\hline Venus clam & 36,691 & $11,180,397$ & 36,691 & $11,180,397$ \\
\hline Others & 1,629 & $4,950,591$ & 1,629 & $4,950,591$ \\
\hline Total & 486,804 & $364,015,706$ & 426,481 & $354,313,733$ \\
\hline
\end{tabular}

$\dagger$ Stocks for which MSY scenario data were calculated.

$\$$ All prices were derived from Table 1 .

\section{DISCUSSION}

The need for regional cooperation on fisheries management across the Black Sea is widely recognized (Duzgunes and Erdogun 2008, Black Sea Commission 2009), not only to prevent further deterioration of the marine environment but also to safeguard the livelihoods of coastal communities in all countries. Attempts to introduce regional governance structures for the management of fisheries in the Black Sea have not been successful. Although the Black Sea Commission advisory group on Environmental Aspects of the Management of Fisheries and Other Living 
Table 6. Estimated annual average economic yields derived from anchovy catches by Turkish fishers under historic and Good Environmental Status (GEnS) and GEnS plus reduced fishmeal scenarios.

\begin{tabular}{|c|c|c|c|c|c|}
\hline Scenario & Product/Market & $\begin{array}{c}\text { Ave. price } \\
(€ / \mathrm{kg}) \dagger\end{array}$ & $\begin{array}{c}\text { Catch } \\
\text { (tonnes) }\end{array}$ & $\begin{array}{c}\text { Value } \\
(€)\end{array}$ & $\begin{array}{c}\text { Utilization } \\
(\%)\end{array}$ \\
\hline \multirow[t]{3}{*}{$2006-2010$} & Anchovy (human consumption) & 0.79 & 114,404 & $90,344,607$ & 44 \\
\hline & Anchovy (fishmeal) & 0.21 & 144,709 & $29,811,385$ & 56 \\
\hline & Weighted overall & 0.46 & 259,113 & $120,155,992$ & \\
\hline \multirow[t]{3}{*}{ GEnS } & Anchovy (human consumption) & 0.79 & 75,745 & $59,816,046$ & 44 \\
\hline & Anchovy (fishmeal) & 0.21 & 95,810 & $19,737,749$ & 56 \\
\hline & Weighted overall & 0.46 & 171,556 & $79,553,795$ & \\
\hline \multirow[t]{3}{*}{ GEnS + } & Anchovy (human consumption) & 0.79 & 91,075 & $71,921,865$ & 53 \\
\hline & Anchovy (fishmeal) & 0.21 & 80,481 & $16,579,709$ & 47 \\
\hline & Weighted overall & 0.52 & 171,556 & $88,501,575$ & \\
\hline
\end{tabular}

$\dagger$ Prices are adjusted to two significant figures; values are calculated on the basis of actual prices.

Marine Resources has sought to promote improved fisheries management, no single body is recognized as providing scientific advice. Attempts to improve cooperation on scientific research and advice (for example, the GFCM Working Group on Black Sea Fisheries, which met for the first time in 2012) have been undermined by the weak institutional framework, which is subject to inconsistent funding and political interference (Knudsen 2013). The GFCM reported in 2011 that, in spite of strong encouragement for scientists of the Black Sea area to actively participate in the subcommittees of the GFCM, no formal stock assessment reports had been submitted (GFCM Secretariat 2011).

Several of the most important commercial fisheries of the Black Sea fall within the definition of straddling fish stocks and highly migratory fish stocks within the terms of UNCLOS. This obliges adherent coastal states to seek "either directly or through appropriate subregional or regional organizations, to agree upon the measures necessary for the conservation of these stocks in the adjacent area." The 1995 UN Fish Stocks Agreement, which came into force in 2001, creates a detailed framework for the management and conservation of such stocks, and specifically contains a duty to cooperate (including specific reference to RFMOs) and to ensure coherence between fisheries management measures within the exclusive economic zones and on the high seas. Five of the six Black Sea nations have ratified UNCLOS. However, Turkey has not, largely due to the implications for Turkey regarding territorial claims in the Aegean.

Accession of Bulgaria and Romania to the EU in 2007 has brought a new rigor to the scientific and management approach within the frame of the EU's Common Fisheries Policy and MSFD. Any future accession of Turkey to the EU could extend these instruments and bring an expanded subregional approach to fisheries management. Legislation introduced by the EU in October 2012 (European Union 2012) has created the potential for trade sanctions (such as quantitative restrictions on importations of fish from stocks of common interest or associated species) against states that do not cooperate in management of such stocks that they share with the EU. However, it is not clear whether this could be lawfully applied in the Black Sea, nor whether it would be effective. In any case, it is doubtful that expanded European jurisdiction within the Black Sea alone can deliver sustainable fisheries due to the shared and straddling nature of most stocks. The need for an RFMO remains clear.

Lack of clear nomination of responsibility for scientific advice, combined with the lack of an agreed mechanism for setting and sharing fishing opportunities between the coastal states, allows the present unsustainable exploitation patterns to continue. In particular, as long as migratory small pelagic fisheries are managed at the national and subregional levels, catches and stocks are unlikely to remain stable, and the risk of further stock collapses remains high.

The economic analyses we have presented do not reflect the full ecological complexity of the Black Sea. While the use of scientific assessments provides an ideal basis for the establishment of GEnS based on MSY, it may not provide the most suitable approach in all cases. As ICES (2013) points out, estimates based on single species assessments do not account for predator-prey interactions or linkages to ecosystem productivity. These factors are much in evidence in the Black Sea, where there are strong trophic interactions linked to eutrophication (Llope et al. 2011). In addition, some of the most commercially important species are short-lived small pelagic fish (particularly forage fish) whose economic utilization depends on their size and year class. The benefits derived from Black Sea fisheries may therefore be strongly linked to the trophic level at which the fishery system is exploited.

Although there is a long history of inadequate environmental management in the Black Sea region, there is an emerging consensus on the need for improved management of fisheries. While this is based largely on ecological considerations, an economic analysis can potentially contribute additional arguments, based on socioeconomic impacts of the fisheries, for addressing the current management vacuum.

The work of the EWGBS and the estimations of economic value of the Black Sea fisheries we have presented indicate that a scenario of GEnS for Black Sea fish stocks could be expected to deliver $97 \%$ of the economic value achieved by the current pattern of exploitation. The scenario would be based on restoring five of the most important stocks to levels that would deliver MSY, with the assumption that there would be no changes in unit value of the catches. Under an MSY scenario, the added value attributed annually to the anchovy catch would show a significant decline 
of $€ 52.1$ million, representing 34\% of the average catch value in recent years, but this would be partially compensated for by increased catches of recovered stocks at higher trophic levels (e.g., turbot and horse mackerel). The Turkish small pelagic fleet, which accounts for $86 \%$ of the anchovy catches, would suffer the greatest potential impact in the longer term (losing approximately $€ 40$ million of value added annually). However, since Turkey also catches about $65 \%$ of the stocks that would sustain increased catches, this loss would be at least partially compensated for by increased fishing opportunities for other fleet segments.

Since it is postulated that the presence of healthy fish stocks at different trophic levels could help limit the impacts of eutrophication and nonindigenous species on the marine environment (Llope et al. 2011), effective fisheries management may also underpin improvements in other descriptors of GEnS and the ecosystem services associated with them. For example, decreased eutrophication, which could result from improved food web structure (Llope et al. 2011), has a significant nonmarket value. Taylor and Longo (2010) have estimated that in Bulgaria alone this could amount to the equivalent of a one-off capital investment of $€ 57$ million.

Another feature of the present management arrangements is the opportunity cost due to suboptimal utilization of a significant part of the catch used for reduction. Fishmeal plants operate in Ukraine and Georgia, but most are located in Turkey, where private investment in fishmeal capacity was supported by public funds throughout the 1980s and 1990s (MacAlister Elliott and Partners 1995). Modern pelagic fishing and processing technologies are still not widely applied in the Turkish fishery sector. Proven technologies in vessel design, product handling and storage, grading, and processing of small pelagic fish, which are used elsewhere, could be expected to deliver significant added value from the catches of small pelagic fish (both anchovy and horse mackerel).

In addition, achieving GEnS for Black Sea fish stocks would impact not only the overall volume of catches but also catch composition as age distribution recovers to reflect a greater proportion of mature fish. Across all stocks, increases in average size could be expected to deliver increased economic yields due to higher unit values at first sale. This is particularly the case in relation to anchovy, where drawing on the EWGBS data for the period 2002-2010, the sum of fish in year class 0 and 1 constituted $51 \%$ of the anchovy catch in weight. Anchovy achieves maturity only in the summer of year 1 and may typically live to year class 3 , which suggests that there is significant scope for allowing fish to grow larger, with a greater proportion of the catch available for higher value markets for human consumption.

It is important to recognize that the estimates of benefits under a future GEnS scenario do not reflect the interim cost of achieving that status, which could be considerable. Rebuilding stocks to levels that deliver MSY implies reducing interim catches to levels that allow rebuilding of spawning stocks. This would require critical policy decisions to select measures that balance biological recovery with socio-economic impacts. A full assessment of the costs and benefits should reflect the policy measures needed to lessen possible negative social impacts (for example, due to reductions in fleet size) and to support structural changes in fishing capacity and onshore processing. For example, financial support measures could contribute to the costs of withdrawal of vessels and create incentives for investment in improved catch utilization, such as grading and freezing. A full assessment should also consider the timing of the costs and benefits since these are not sustained or delivered concurrently. These estimates do not take into account the discounting of changes in financial flows over time, which would influence the analysis since costs would be sustained from the moment of introduction of new management measures, while benefits would be delivered only after stock recovery. Quaas et al. (2012) have suggested a methodological approach that regards costs of fisheries management measures as investments that deliver a return in terms of improved yields, which is applicable to this situation.

\section{CONCLUSIONS}

Few authors believe that the Black Sea can be returned to its pristine state. As stated by Daskalov et al. (2007), the aim of management in the Black Sea must be to restore the ecosystem to a balanced state with the potential to provide sustainable use of its essential goods and services. Daskalov et al. go on to state "Recovery of a resilient ecosystem should mean restoring all important components (including top predators) into the new desirable state: reducing the anthropogenic impact, normalizing species interactions, buffering trophic cascades, increasing biodiversity and improving environmental quality. Such a state of the ecosystem would provide strategic benefits, such as a clean marine environment, abundant and diverse fish stocks and sustainable economic activities (e.g., fishing, tourism), to a range of stakeholders and society as a whole."

In the Black Sea region, long-standing attempts to improve fisheries management have so far not been successful, and lack of regional cooperation on fisheries remains one of the major barriers to effective environmental management. From the management perspective (following Knipovitch 1932) the Black Sea may be characterized succinctly as a unicum hydrobiologicum unicis populisque, that is, a unique biological system with unique peoples. Notwithstanding Turkey's nonratification of UNCLOS, there is nothing in international law to prevent the parties from applying voluntarily the principles therein, and establishing an RFMO for the Black Sea.

However, the need for effective collaboration on environmental matters, including fisheries, is not reflected in the agenda for international relations within the region, which, for many of the coastal states, is substantially driven by strong geopolitical motives. Until now, the economic arguments have not been clearly expressed. The ongoing policy debate between, and within, Black Sea coastal states needs to be extended to include recognition of the potential economic and social benefits of effective fisheries management.

The results of this study show that, in the long term, achieving GEnS of the Black Sea commercial fisheries by managing stocks to deliver MSY would provide economic benefits to coastal communities of the same order as currently achieved, even with a substantial one-third reduction in anchovy catches (which would impact mostly the Turkish small pelagic fleet). There would be compensatory benefits for other fleet segments, and further value added could also be derived from targeted investment in improved market utilization of the small pelagic catch for human consumption (rather than fishmeal).

The potentially negative impacts of a policy to establish GEnS in Black Sea fisheries are quantifiable and limited in their scope. 
There is a need for the parties to take greater account of the costs and benefits of achieving GEnS in assessing their interest in improved management of fisheries. The discussions on an RFMO should be extended to the need for financial support mechanisms for fleet capacity adjustment (for example, to compensate displaced fishers for loss of livelihoods). Such measures need to be considered within Turkey's EU accession agenda. Overall, addressing the economic arguments may provide a more effective means of galvanizing the political will required to achieve the EU's environmental goals in the Black Sea rather than directly promoting the paradigm shift in environmental values espoused by the EU's Marine Strategy Framework Directive.

Responses to this article can be read online at: http://www.ecologyandsociety.org/issues/responses. $\mathrm{php} / 6817$

\section{Acknowledgments:}

The research leading to these results has received funding from the European Community's Seventh Framework Programme [FP7/2007-2013] under grant agreement No.226675 (The KnowSeas Project: Knowledge-based Sustainable Management for Europe's Seas).

\section{LITERATURE CITED}

Black Sea Commission. 2008. State of the environment of the Black Sea (2001-2006/7). Temel Oguz, editor. Publications of the Commission on the Protection of the Black Sea against Pollution (BSC) 2008-3. Istanbul, Turkey.

Black Sea Commission. 2009. Implementation of the Strategic Action Plan for the rehabilitation and protection of the Black Sea (2002-2007). Publications of the Commission on the Protection of the Black Sea against Pollution (BSC) 2009-1. Istanbul, Turkey.

Bodeanu, N. 2002. Algal blooms in Romanian Black Sea waters in the last two decades of the 20th century. Recherche Marines $34: 7-22$.

Brodziak, J., J. Ianelli, K. Lorenzen, and R. D. Methot, Jr. 2009. Estimating natural mortality in stock assessment applications. NOAA Technical Memorandum NMFS-F/SPO-119.

Cadima, E. L. 2003. Fish stock assessment manual. FAO Fisheries Technical Paper No. 393. FAO, Rome, Italy.

Cociasu, A., L. Dorogan, C. Humborg, and L. Popa. 1996. Longterm ecological changes in Romanian coastal waters of the Black Sea. Marine Pollution Bulletin 32:32-38. http://dx.doi. org/10.1016/0025-326X(95)00106-W

Daskalov, G. M., A. N. Grishin, S. Rodionov, and V. Mihneva. 2007. Trophic cascades triggered by overfishing reveal possible mechanisms of ecosystem regime shifts. Proceedings of the National Academy of Sciences of the United States of America 104:10518-10523. http://dx.doi.org/10.1073/pnas.0701100104

Daskalov G., A. Gümüş, V. Maximov, M. Panayotova, G. Radu, V. Raykov, V. Shlyakhov, M. Zengin, H. J. Rätz, R. Scott, and J. N. Druon. 2010. Review of scientific advice for 2010-Part 3b. Advice on stocks of interest to the European community in the
Black Sea Scientific, Technical and Economic Committee for Fisheries, Joint Research Centre-Institute for the Protection and Security of the Citizen Luxembourg: Office for Official Publications of the European Communities 2010 EUR-Scientific and Technical Research series. http://dx.doi.org/10.2788/80318

Duzgunes, E., and N. Erdogan. 2008. Fisheries management in the Black Sea countries. Turkish Journal of Fisheries and Aquatic Science 8:181-192.

European Commission. 2008. Directive 2008/56/EC of the European Parliament and of the Council of 17 June 2008 establishing a framework for community action in the field of marine environmental policy. Official Journal of the European Union 25.6.2008 L 164/19.

European Commission. 2010. Commission Decision of 1 September 2010 on criteria and methodological standards on good environmental status of marine waters (notified under document C(2010) 5956)(2010/477/EU)). Official Journal of the European Union L232, 12e24.

European Union. 2011. Parliament resolution of 13 September 2011 on current and future management of Black Sea fisheries (2010/2113(INI)). Text adopted by European Parliament, single reading T7-0365/2011 (Summary) 13/09/2011. [online] URL: http://www.europarl.europa.eu/sides/getDoc.do?type=TA\&language= EN\&reference $=$ P7-TA-2011-365

European Union. 2012. Council Regulation (EU) No 1026/2012 of the European Parliament and of the Council on certain measures for the purpose of the conservation of fish stocks in relation to countries allowing non-sustainable fishing. Official Journal of the European Union 14.11.2012 L 316/34.

Expert Working Group on Assessment of Black Sea Stocks (EWGBS). 2011. Assessment of Black Sea stocks (STECFOWP-11-04). Sofia, Bulgaria, 10-14 October 2011. Report to the Scientific, Technical and Economic Committee for Fisheries (STECF).

Fisheries Global Information System (FIGIS). 2013. GFCM (Mediterranean and Black Sea) capture production database. FAO Fisheries and Aquaculture Department. [online] URL: http://www.fao.org/fishery/statistics/gfcm-capture-production/en

Food and Agriculture Organization of the United Nations (FAO). 2006. Stock assessment for fishery management: a framework guide to the stock assessment tools of the Fisheries Management Science Programme. FAO Fisheries Technical Paper No. 487. FAO, Rome, Italy.

Food and Agriculture Organization of the United Nations (FAO). 2008. Fishery and aquaculture country profile: Turkey. [online] URL: http://www.fao.org/fishery/facp/TUR/en

Froese, R., and D. Pauly, editors. 2011. FishBase. World Wide Web electronic publication. [online] URL: www.fishbase.org

General Fisheries Council of the Mediterranean (GFCM) Secretariat. 2011. Status of the GFCM actions in the Black Sea. 13th session of the Scientific Advisory Committee, 7-11 February 2011, Marseille, France. [online] URL: http://151.1.154.86/ GfcmWebSite/SAC/13/ppt/SAC13 Black Sea.pdf

Gulland, J. A. 1971. The fish resources of the ocean. Fishing News Books Ltd., West Byfleet, England. 
Haddon, M. 2001. Modelling and quantitative methods in fisheries. Chapman \& Hall/CRC Press, Boca Raton, Florida.

Hilborn, R., and C. J. Walters. 1992. Quantitative fisheries stock assessment. Choice, dynamics and uncertainty. Kluwer Academic Publishers, Norwell, Massachusetts, USA. http://dx.doi. org/10.1007/978-1-4615-3598-0

Hoggarth, D. D., S. Abeyasekera, R. I. Arthur, J. R. Beddington, R. W. Burn, A. S. Halls, G. P. Kirkwood, M. McAllister, P. Medley, C. C. Mees, G. B. Parkes, G. M. Pilling, R. C. Wakeford, and R. L. Welcomme. 2006. Stock assessment for fishery managementa framework guide to the stock assessment tools of the Fisheries Management Science Programme (FMSP). FAO Fisheries Technical Paper No. 487. FAO, Rome, Italy.

International Council for the Exploration of the Sea (ICES). 2012. MSFD D3 Report, ICES Advisory Committee, ICES CM 2012/ACOM:62, Marine Strategy Framework DirectiveDescriptor 3+, Revised 22 February 2012.

International Council for the Exploration of the Sea (ICES). 2013. General context for ICES advice. [online] URL: http://www. ices.dk/sites/pub/Publication\%20Reports/Advice/2013/2013/1.2_General context of ICES advice 2013 June.pdf

International Union for Conservation of Nature (IUCN). 2012. The IUCN Red List of threatened species. Version 2012.2 [online] URL: http://www.iucnredlist.org

Knipovich, N. M. 1932. The hydrological investigations in the Black Sea (in Russian). Tr AzovoChernomorsk Nachnopomysl Eksped.

Knudsen, S. 2013. Marine governance in the Black Sea. In M. Gilek and K. Kern, editors. Marine Governance in Europe. Ashgate.

Knudsen, S., M. Zengin, and M. H. Koçak. 2010. Identifying drivers for fishing pressure. A multidisciplinary study of trawl and sea snail fisheries in Samsun, Black Sea coast of Turkey. Ocean \& Coastal Management 53:252-269. http://dx.doi.org/10.1016/j. ocecoaman.2010.04.008

Llope, M., G. M. Daskalov, T. A. Rouyer, V. Mihneva, K-S. Chan, A. N. Grishin, and N. C. Stenseth. 2011. Overfishing of top predators eroded the resilience of the Black Sea system regardless of the climate and anthropogenic conditions. Global Change Biology 17:1251-1265. http://dx.doi.org/10.1111/j.1365-2486.2010.02331. $\underline{\mathrm{x}}$

MacAlister Elliott and Partners. 1995. Fish marketing in Turkey. Volume 6: Utilization and marketing of small pelagic fish. Lymington, Hampshire, UK.

Mee, L. D., J. Friedrich, and M. T. Gomoiu. 2005. Restoring the Black Sea in times or uncertainty. Oceanography 18:100-111. http://dx.doi.org/10.5670/oceanog.2005.45

O'Higgins, T., A. Farmer, G. Daskalov, S. Knudsen, and L. Mee. 2014. Achieving good environmental status in the Black Sea: scale mismatches in environmental management. Ecology and Society, Volume 14 In press.

Oguz, T., B. Fach, and B. Salihoglu. 2008. Invasion dynamics of the alien ctenophore Mnemiopsis leidyi and its impact on anchovy collapse in the Black Sea. Journal of Plankton Research 30:13851397. http://dx.doi.org/10.1093/plankt/fbn094

Öztürk, B., C. Keskin, and S. Engin. 2011. Some remarks on the catches of anchovy, Engraulis encrasicolus (Linnaeus, 1758), in Georgian waters by Turkish fleet between 2003 and 2009. Journal of the Black SealMediterranean Environment 17:145-158.

Pauly, D. 1980. On the interrelationships between natural mortality, growth parameters, and mean environmental temperature in 175 fish stocks. Journal du Conseil International Pour l'Exploration de la Mer 39:175-192.

Pauly, D., V. Christensen, J. Dalsgaard, R. Froese, and F. Torres, Jr. 1998. Fishing down marine food webs. Science 279:860-863. http://dx.doi.org/10.1126/science.279.5352.860

Prodanov, K., K. Mikhailov, G. M. Daskalov, C. Maxim, A. Chashchin, A. Arkhipov, V. Shlyakhov, and E. Ozdamar. 1997. Environmental management of fish resources in the Black Sea and their rational exploitation. FAO: General Fisheries Council for the Mediterranean, Rome, Italy.

Quaas, M. F., R. Froese, H. Herwartz, T. Requate, J. O. Schmidt, and R. Voss. 2012. Fishing industry borrows from natural capital at high shadow interest rates. Ecological Economics 82:45-52. http://dx.doi.org/10.1016/j.ecolecon.2012.08.002

Quinn, T. J., II., and R. B. Deriso. 1999. Quantitative fish dynamics. Oxford University Press, Oxford, UK.

Rätz, H-J., H. Dörner, R. Scott, and T. Barbas. 2010. Complementary roles of European and national institutions under the Common Fisheries Policy and the Marine Strategy Framework Directive. Marine Policy 34:1028-1035. http://dx.doi.org/10.1016/ j.marpol.2010.03.001

Scientific, Technical and Economic Committee for Fisheries (STECF). 2011. Assessment of Black Sea stocks (STECFOWP-11-06). Opinion by written procedure. Georgi Daskalov and Hans-Joachim Ratz, editors. Sofia, Bulgaria, 10-14 October 2011.

Sinclair, A. F. 2001. Natural mortality of cod (Gadus morhua) in the southern Gulf of St Lawrence. ICES Journal of Marine Science 58:1-10. http://dx.doi.org/10.1006/jmsc.1999.0490

Sparre, P., and S. C. Venema. 1998. Introduction to tropical fish stock assessment. Part 1. Manual (Rev. 2). FAO Fisheries Technical Paper No. 306.1. FAO, Rome, Italy.

Suárez De Vivero, J. L. 2012. Fisheries cooperation in the Mediterranean and the Black Sea. Directorate-General for Internal Policies, Policy Department Structural and Cohesion Policies. European Parliament. IP/B/PECH/IC/2012-069. November 2012.

Taçon, A. G. J., and M. Metian. 2009. Fishing for feed or fishing for food: increasing global competition for small pelagic forage fish. Ambio 38:294-302. http://dx.doi.org/10.1579/08-A-574.1

Taylor, T., and A. Longo. 2010. Valuing algal bloom in the Black Sea coast of Bulgaria: a choice experiments approach. Journal of Environmental Management 91:1963-1971. http://dx.doi.org/10.1016/ j.jenvman.2010.04.007 
Temmuz. 2010. Türkiye Cumhuriyeti Başbakanlik Yatırım Destek ve Tanıtım Ajansı. [online] URL: http://www.slideshare. net/KocaeliKasiad/gida-sektr-raporu

Turkish Statistical Institute. 2012. Fishery statistics 2011. Ankara, Turkey.

Vassileva, I. 2011. Speech by Deputy Minister for Environment and Water, Bulgaria, at the "High Level Session: How can an integrated approach to maritime affairs benefit the environmental protection of the Black Sea, notably the implementation of the Marine Strategy Framework Directive", Brainstorming Event on Maritime Affairs and Fisheries with Bulgarian and Romanian Authorities. European Commission, Brussels, Belgium. 14 October 2011.

World Bank. 2011. World development indicators 2011. World Bank Press.

Yıldırım, Ö. 2006. 'Sinop ili balık unu-yağı fabrikalarının mevcut durumu ve Türkiye balık unu-yağı üretimindeki yeri'. Fırat Üniversitesi Fen ve Mühendis Bilimler Dergisi, 18:197-203. 